\title{
Paideusis
}

\section{Academic Freedom in the Religious College and University: Confronting the Postmodernist Challenge}

\section{Elmer J. Thiessen}

Volume 11, Number 2, 1998

URI: https://id.erudit.org/iderudit/1073105ar

DOI: https://doi.org/10.7202/1073105ar

See table of contents

Publisher(s)

Canadian Philosophy of Education Society

ISSN

0838-4517 (print)

1916-0348 (digital)

Explore this journal

Cite this article

Thiessen, E. (1998). Academic Freedom in the Religious College and University: Confronting the Postmodernist Challenge. Paideusis, 11(2), 55-72.

https://doi.org/10.7202/1073105ar 


\title{
Academic Freedom in the Religious College and University: Confronting the Postmodernist Challenge
}

\author{
EImer J. Thiessen, Medicine Hat College
}

Religiously-based colleges and universities are committed to a certain faith stance which affects not only what is taught but also who does the teaching. Faculty are often required to sign a statement of faith before they are hired. Certain standards of behaviour, reflecting the supporting constituencies' values are often also required of faculty. Teaching and research are expected to be in keeping with the basic faith commitment of the institution. Failure to stay within these boundaries sometimes leads to the dismissal of the faculty member.

Such expectations would seem to be a blatant violation of the principle of academic freedom which is thought to undergird healthy liberal educational institutions. Hence, the following charge against such schools by Robert M. McIver: "To make the university a center for the propagation of any creed, of any system of values that divides group from group, is to destroy the special quality and the unique mission of the university as a center for the free pursuit of knowledge wherever it may lead."1 A 1988 report of a subcommittee of the American Association of University Professors (AAUP) Committee A on Academic Freedom and Tenure is even more explicit. It suggests that the "necessary consequence" of religious institutions invoking the limitations clause in the AAUP Statement on Academic Freedom is that they forfeit "the moral right to proclaim themselves as authentic seats of higher learning.",

The purpose of this paper is to respond to charges such as these. I argue that religious colleges and universities do not of necessity violate the principle of academic freedom which is so sacred to the liberal educational establishment. My approach is to challenge some of the assumptions underlying the traditional concept of academic freedom. ${ }^{3}$ I then propose a revised ideal of academic freedom on the basis of which I hope to show that religious colleges and universities can have the required level of academic freedom which would make them authentic seats of higher leaming just like their secular counterparts.

\section{Historical Observations}

The standard contemporary ideal of academic freedom has a variety of roots: a medieval concern to protect quasi-ecclesiastical universities from undue interference from the temporal power of the state, the turn-of-the-century German ideal of Lehrfreiheit-the right of a university professor to freedom of inquiry and teaching, the Enlightenment, the ideals of the French revolution, and John Stuart Mill's classic defence of freedom. The modern secular university grew out of a conscious attempt to free scholarly investigation from the supposed strictures that had dominated scholarship prior to the Enlightenment, particularly those of religious tradition and authority. And academic freedom was seen as the central tenet of the modern secular university (McConnell, 1993, p.
306).

Editor's Note: This article first appeared in Paideusis, 10(1), 1996. Quite inadvertently, the Notes were omitted. We apologize to Professor Thiessen and reprint the article in its entirety. 
Although there are a variety of concerns connected with the modern ideal of academic freedom, the central concern is the protection of the right of faculty members to research, publish, teach, or even to express themselves outside of the college/university. This freedom is generally qualified as applying to matters within faculty members' area of professional competence, and subject to the professional standards of their respective disciplines and the adequate fulfilment of their professional duties. ${ }^{4}$

Here, it might be helpful to look specifically at an influential American statement of academic freedom, paying particular attention to its accommodation of religious colleges and universities. 5 The standard American ideal of academic freedom can be traced to the founding of the American Association of University Professors (AAUP) in 1915, with John Dewey as its first president. While the founding of AAUP was largely rooted in a need to protect professors who were being fired because they had defended controversial political views, dismissals on religious grounds was also an initial concern (Marsden, 1993, p. 221). In the next few decades, a widespread consensus emerged concerning academic freedom, which led to the formulation of the very influential 1940 "Statement of Principles on Academic Freedom and Tenure." 6 In this statement, freedom in teaching and research is defended as essential to institutions of higher education and their promotion of the common good.

A precautionary "limitations clause" was included in the 1940 statement so as to accommodate parochial schools: "Limitations of academic freedom because of religious or other aims of the institution should be clearly stated in writing at the time of appointment" (Van Alstyne, 1993, p. 407). Here, it is important to note that this qualification is viewed as a "limitation" on the "full" academic freedom that should characterize genuine institutions of higher learning. From the beginning, controversy has surrounded this limitations clause. In a 1970 "Interpretive Comment" on the 1940 Statement, AAUP declared that "most church-related institutions no longer need or desire the departure from the principle of academic freedom implied in the 1940 Statement, and we do not now endorse such a departure" (Marsden, 1993, p. 232).

Marsden goes on to suggest that this more purist attitude towards academic freedom has remained a prominent stance in the AAUP and within American academia generally. Indeed, if one examines the many reports issued by AAUP's Committee $A$ on Academic Freedom and Tenure, which investigates alleged violations of academic freedom, it is clear that Committee $A$ has repudiated the limitations clause of the 1940 Statement and is assuming only the secular understanding of academic freedom (McConnell, 1993, p. 311). ${ }^{8}$

Among the more celebrated recent cases of a supposed violation of academic freedom at a religious school is that of Father Charles E. Curran's 1986 removal at the Vatican's order from the theology faculty of the Catholic University of America because of his liberal views on sexual morality, abortion, and other social issues. In a recent book that not only documents his own struggle but also provides a fascinating overview of the debate over academic freedom within Catholic higher education, Curran (1990) argues for full academic freedom at Catholic universities. Curran's case provides an example of someone within a religious educational context who is essentially agreeing with the standard secular ideal of academic freedom and, on that basis, condemning what is occurring in Catholic higher education. 
Professional organizations have similar concerns about academic freedom and base their concerns on a very similar foundation. For example, the Canadian Society for the Study of Religion (CSSR) recently investigated a case involving a faculty member (at Saint Stephen's College affiliated with the University of Alberta) whose contract was not renewed on grounds that appeared to have no academic basis. An ad-hoc committee of CSSR produced a report recommending that the Canadian Association of University Teachers' (CAUT) guidelines on academic freedom be applied to all academics teaching religion in Canadian universities, schools of theology, colleges, and seminaries, and that a distinction not be drawn between the rights of academics teaching theology in seminaries as opposed to the rights of academics teaching religion in universities. CSSR further initiated a request to have other theologically oriented societies join them in meeting with the CAUT to discuss the issue of academic freedom in theological and church-related colleges in Canada. ${ }^{9}$

It should be clear from this historical review that the general consensus among the secular educational establishment is that such institutions simply cannot have full academic freedom because of their religious commitment and, therefore, they forfeit "the moral right to proclaim themselves as authentic seats of higher learning." 10

How, then, do educationalists in religious institutions respond to this charge? Various approaches are taken. Father Charles Curran has shown that Roman Catholics are divided in their response, some defending Catholic schools by challenging the traditional statement of academic freedom, others arguing for limited academic freedom, some like Curran arguing that Catholic institutions of higher learning should have the same level of academic freedom as their secular counterparts, and some arguing that there is even greater academic freedom at Catholic schools than at their secular counterparts (Curran, 1990). A similar variety of responses can be found among Protestant and evangelical
academics. ${ }^{11}$

\section{A Problem of Definition}

One of the basic problems with the traditional concept of "academic freedom" is that it lacks a clear and precise meaning. Already in its early usage in America, vagueness and inconsistencies were evident. To advocate "full freedom," while at the same time arguing for "duties correlative to rights," or "appropriate restraint" in the light of one's status as a professional and as a citizen, as is done in the AAUP 1940 Statement, is simply to be inconsistent (Van Alstyne, 1993, pp. 407-9). Marsden points out that the original AAUP committee members recognized that academic freedom could not be unlimited, "but they argued that there should always be a presumption in its favour, with no firm lines drawn around it" (Marsden, 1993, p. 229). The lines were, indeed, not firm! Hence, the condoning of blatant restrictions of academic freedom in the name of the national interest prior to World War I by academics and some of the original founders of the AAUP, even to the point of AAUP adopting a special revised statement of academic freedom, entitled "Academic Freedom in Wartime"' (Marsden, 1994, pp. 309-11).

The fact of continuing controversy about the existence of academic freedom in state-maintained colleges and universities would seem to add further weight to the claim that the concept itself is fraught with difficulties. The very 11(2), (Winter) 1998 
titles of books are suggestive: Illiberal Education: The Politics of Race and Sex on Campus (D'Souza 1991); The Closing of the American Mind (Bloom 1987); Zealotry and Academic Freedom (Hamilton, 1995); and Kindly Inquisitors: New Attacks on Free Thought (Rauch, 1993). Of course, the claims of these and other conservative critics of contemporary demands for ideological conformity and "political correctness" which have encroached on academic freedom at our colleges and universities are disputed by "radicals" such as Tierney (1993). I will be returning to this dispute later, but here my intent is only to point out that this dispute would seem to suggest a problem with the concept of academic freedom itself.

One final indication of the problematic nature of the traditional ideal of academic freedom is that many religiously-based schools do maintain that academic freedom is an operative principle within their institutions, as has already been pointed out earlier. Now obviously, these claims and the statements of academic freedom within these schools will not satisfy many academics who see themselves as religiously uncommitted. At this point in my argument, I do not want to resolve this dispute. I have drawn attention to these controversies only to highlight the fact that the question of the existence of academic freedom at religiously-based colleges and universities is not as clear-cut as many assume.

Underlying the debate concerning the presence or absence of academic freedom at either religious or secular schools is a problematic definition of academic freedom. As Marsden concludes, "it is a concept fraught with deep ambiguities"' $\left(1993\right.$, p. 231). ${ }^{12}$ More attention, therefore, needs to be paid to defining what we mean by academic freedom.

\section{Problems with the Traditional Ideal of Academic Freedom}

1. Freedom: At the heart of current conceptions of academic freedom is an assumption of absolute individual intellectual freedom in research and teaching. ${ }^{13}$ I have already made reference to the tension inherent in the AAUP's early attempts to define the level of freedom possible in academic freedom. The 1940 Statement as a whole breathes a "spirit of untrammelled inquiry," as one early Catholic critic put it. ${ }^{14}$ Thus, we are reminded in the 1940 Statement that the teacher is entitled to "full freedom" in research and in the publication of the results (Van Alstyne, 1993, p. 407). It is further significant that although the Statement seems to acknowledge the right of religious educational institutions to impose certain religious requirements on teaching employees, such requirements are seen as "limitations" of academic freedom. The assumption is that "full" academic freedom would have no such restrictions. The failure to endorse this limitation clause in the AAUP 1970 "Interpretive Comment" on the 1940 Statement would again suggest that the ideal is seen as that of having full academic freedom.

Current conceptions of academic freedom, I would suggest, are rooted in a concept of freedom which has its origins in the Enlightenment. One important legacy of the Enlightenment that remains to this day is the belief in free inquiry, inquiry that is freed entirely from the constraints of tradition and authority, particularly as found in religion (cf. Hamilton, 1995, p. 160).

But, the notion of absolute freedom is a myth. Freedom, whether individual, social, or political, is necessarily limited. Freedom is always freedom in context. Indeed, it can be argued that freedom is only possible in the context 
of that which restricts freedom. Hence, notions of "full" freedom in research and teaching are by their very nature problematic.

This conclusion is reinforced in Haworth's attempt to counter the romantic notions of autonomy that still abound which he replaces with a more coherent, comprehensive and realistic account of "normal autonomy" (Haworth, 1986). Haworth further stresses the institutional context within which autonomy must express itself. And while institutional structures do have a face of constraint, he argues that they also have a face of opportunity (Haworth,
1986 , ch. 6).

Polanyi has underscored the institutional context of scientific research, often put forward as the paradigm of free inquiry. For example, students must submit to those who have mastered the science, and scholars are awarded grants which are distributed according to certain criteria and whose proposals are refereed by other colleagues. Publication of the findings of scientists are subject to all kinds of controls, and if they depart too far from established opinion, they may not be successful in getting their work published (Polanyi, 1946 [1964], ch. 2). So even in science, the spirit of inquiry is not utterly unfettered as is so often assumed. Hence, typical statements of academic freedom are forced to acknowledge the constraints imposed on academics by the academic disciplines
themselves. 15

Teaching similarly is subject to a host of constraints. Teachers first need to be educated and certified. They teach in schools which are subject to any number of formal and informal guidelines and pressures, coming from a variety of sources-administration, government, and local sentiments. Any teacher who ignores these does so at his or her peril. Most often, these guidelines are simply assumed and, hence, teachers may not even be aware of them. But the fact that most teachers are not aware of these constraints does not mean that they do not
exist.

It is because there is and can be no such thing as unlimited academic freedom that one invariably finds contradictions in descriptions and definitions of liberal notions of academic freedom. ${ }^{16}$ As Caston warns us, statements of absolute academic freedom, whether applied to the individual academic or to the university as a whole, "are ideals which cannot be, never have been, and arguably should never be, totally realised"' $(1989$, p. 307).

2. Epistemology: Underlying the traditional concept of academic freedom is an epistemology which can only be called "naive" given the more recent developments in this field. At the heart of the contemporary ideal of academic freedom is a spirit of free inquiry which has always been thought to be best exemplified in science. Marsden has clearly shown that underlying the original formation of the AAUP and its position concerning academic freedom was the ideal of free and objective scientific inquiry which would rid us of the parochial past together with the passion, prejudice, and partisanship associated with tradition (Marsden, 1993, pp. 226-31). 17 But developments in the philosophy of science, the sociology of
knowledge, and feminist epistemology-to name but a few-have shown that the search for truth is, in fact, always guided by assumptions and preconceptions which will of necessity function as constraints on freedom of inquiry. 18 The Enlightenment quest for absolute objectivity is inherently futile. It is a quest for a "view from nowhere," as Thomas Nagel (1986) has described it. A view 
from nowhere is impossible because all rational activity is "inescapably historically and socially context-bound" (MacIntyre, 1988, p. 4). The idea of a universal and neutral rationality is now recognized to be itself an expression of a particular narrative, an Enlightenment narrative.

It is crucial to note that it would be a mistake to view the assumptions and preconceptions that any rational person begins with as functioning only as constraints on freedom of inquiry. While functioning as limitations in one sense, they must also be seen as preconditions of rationality. In other words, they make possible the search for truth.

Advocates of the traditional ideal of academic freedom err further in their epistemology by assuming that a commitment to certain religious presuppositions precludes an honest and open search for the truth. Open-mindedness is not the same as empty-mindedness (Hare, 1979, p. 53). Indeed, there are no empty minds. Locke's tabula rasa is a myth.

The prevailing ideal of academic freedom rests on an epistemology which is now generally recognized to be fundamentally flawed. Indeed, it is surprising that the 1940 formulation of academic freedom by AAUP, and others very similar to it, still persist. They are in desperate need of updating. 19 The suspicion of any limitations on academic freedom fails to recognize that a researcher or teacher inherits a standpoint from which he or she pursues and expounds the truth.

What is needed, therefore, is a new ideal of academic freedom which recognizes that we are all situated in a particular time and a particular place, and that the best scholarship is honest in admitting the limitations imposed by its prior commitments. Good scholarship will, of course, also go on to defend the possibilities opened up by starting with these prior commitments. ${ }^{20}$

3. Individualism: Another fundamental problem with contemporary definitions of academic freedom involves their extreme individualism. In the AAUP 1940 Statement, for example, it is the individual teacher or the individual researcher who is to be given academic freedom and tenure.

Although the individual is important, we are by nature also social beings, and our search for truth always occurs within the context of a community. ${ }^{21}$ The teacher or researcher is simply not "a socially disembodied being" who can or should be given full freedom in research and teaching (Macintyre, 1988, p. 4). Even scientific scholarship, often seen as the paradigm of free and individual inquiry, typically occurs within the context of a community. Moreover, there is also an institutional context of this scientific research.

One other dimension of institutional limitations on academic freedom needs to be underscored. Educational institutions need financial support and there is always some sort of supporting constituency, whether society at large, as in the case of state-supported colleges and universities, or smaller religious societies, as in the case of religious schools. Such support will always be contingent on these institutions serving in some way the interests of the supporting constituency-hence, the reference in the AAUP 1940 Statement of Academic Freedom to the "common good" (Van Alstyne, 1993, p. 407). But what is not sufficiently acknowledged is the extent to which such a reference to the common good might limit academic freedom (Marsden, 1993, p. 230). Tierney has, therefore, quite correctly pointed out that academic freedom has never existed in a political vacuum $\left(1993\right.$, p. 144). ${ }^{22}$ 
This political dimension of academic freedom is dealt with in Conrad Russell's recent and insightful treatment of the clash between the British government and the universities during the debate over the Education Reform Bill of 1988 (Russell, 1993). Russell argues that there has always been a tension between state support of the university and the freedom of the university. The protection of academic freedom really depends on government, and governments will only provide this protection if they see this to be in their own inter-
ests (Russell, 1993, p. 22).

No university has a natural right to exist, Russell points out $(1993$, p. 47). Hence, governments do not have to support universities. Of course, I believe it would be tragic for a society not to do so, but we as academics need to recognize our dependence on society, and respond honestly and humbly to the concerns of society. ${ }^{23}$ And this obviously imposes limits on our academic freedom. To talk of "full academic freedom" is simply idealistic sky-gazing.

Obviously, there is a danger that society might stifle the freedom of the academic too much. What is needed, therefore, is a more careful definition of a proper balance between the interests of the state and the interests of the academic. ${ }^{24}$ Such a definition will need to acknowledge the limitations that arise from the social and political context within which an academic must work.

\section{The Postmodernist Challenge}

There is clearly a postmodernist ring to my criticisms of the traditional ideal of academic freedom. For postmodernists, the idea of an ahistorical, noncontingent, rational self is a myth and, therefore, complete objectivity is impossible. Knowledge and truth are to some degree relative to place, society, culture, historical epoch, and conceptual framework. Truth needs to be seen as located within the context of discourse communities (Weinstein, 1995, p. 378). Scholarship, too, is necessarily situated within a present and a particular, and a defensible notion of academic freedom needs to recognize this.

Postmodernism at its core is a reaction to the Enlightenment (Carr, 1995, p. 78). And at the core of the Enlightenment, which set the agenda of modernity, was a desire to search for truth apart from tradition and authority. The oral, the particular, the local, and the timely were all viewed with suspicion (Toulmin,

This same emphasis is very much in evidence in early formulations of the traditional Western ideal of academic freedom. Marsden highlights the fact that behind the formation of professional societies such as AAUP in 1915 was a desire "to define and control a national culture at the expense of local cultures." They "were creating loyalties and self-definitions based on the scientific standards of national organizations, and thus undermining loyalty to particular institutions and their traditions" (Marsden, 1993, p. 227; 1994, p. 306). This same spirit created a suspicion of religious educational institutions. Hence, the "limitations clause" of AAUP's first statement on academic freedom. The suspicions about religious colleges and universities remain to this day. 25

At the heart of postmodernism is the attempt to recapture the preEnlightenment respect for tradition and that which is bound to a particular time and place. My critique of the assumptions underlying the modern ideal of academic freedom clearly rests on a postmodernist rejection of the agenda begun 
But here a fundamental problem arises. If, with the postmodernists, I stress the context-bound nature of rationality, am I not opening the door to epistemological relativism? Does not my position also suggest that knowledge is a social and political construction which privileges some and silences others, and which, therefore, calls for a radical reinterpretation of academic freedom in terms of protecting the rights of the silent and the marginalized, thereby enabling them to gain a voice? Such a reinterpretation along the lines of critical theory has been recently attempted by William Tierney (1993). ${ }^{26}$

The problem with such a radical politicization of the notion of academic freedom is that the search for truth is replaced with a battle for survival, "and we are left only with power as the means for adjudicating disagreement" (Bailin, 1992, p. 68). Tierney is quite explicit in calling for a replacement of a "consensual model" of knowledge and academic freedom with a "conflict model in which we assume that competing interests will always exist" (1993, p. 148). Such a conflict model of truth is frankly frightening, and I would suggest that we have yet to reap the full consequences of this model being increasingly accepted in our universities. Here, I can only refer to various conservative critics of the academy who have issued warnings over the last decade about the radical orientation that currently resides in our college and university campuses. ${ }^{27}$ Hamilton (1995) has made a most eloquent plea to counter the latest wave of ideological zealotry in academia coming from the "fundamentalism of the radical academic left."

A further theoretical problem with Tierney's radical postmodernist reinterpretation of academic freedom is that it does away with the notion of truth and the search for a common truth. Tierney is very open about rejecting the conservative ideal of the academy that relies on "a singular notion of truth" towards which we are striving $(1993, \mathrm{pp} .144,147,158)$.

The problem here is that without the notion of truth, or the ideal of searching for truth, we have undermined the very heart of education and research. Indeed, what postmodernists like Tierney fail to realize is that without the notion of truth, they have undermined their own critique of the academy. Why listen to the radicals if they are merely one voice among many other relative voices? Postmodernists further invariably contradict themselves! They seem unable to avoid talking about their postmodern viewpoint as better than that of old-fashioned modernism. But better in terms of what? It seems difficult not to talk about objective and universal truth in some sense. 28

It is here where I am in agreement with a basic idea inherent in the traditional notion of academic freedom-the search for truth is important and we need to protect the search for and the exposition of claims to truth, from arbitrary limitations. While I have been stressing the limitations inherent in our search for truth and our need to be honest about these limitations, I in no way want to do away with the notion that human beings must, and invariably do, attempt to transcend these limitations in their search for universal truth. Without balancing the emphasis on limitations with an equal emphasis on the need to try to transcend these limitations, we end up with epistemological relativism and the radical politicization of the academy which we see on our campuses today.

Here, it might be helpful to return to Nagel. ${ }^{29}$ Although we cannot get a view from nowhere, according to Nagel, there is within each of us an impulse to transcend our particular personal point of view, and this is due to the fact that we 
recognize that it is merely a point of view, a perspective, and not simply an account of the way things are. "The recognition that this is so," he writes, "creates pressure on the imagination to recast our picture of the world so that it is no longer the view from here" (Nagel, 1986, p. 70). In other words, each of us is aware of the possibility that our particular perspective might be wrong, and so we aspire to "the view from nowhere," to a view uncontaminated by any
perspectival factors.

This aspiration which drove the Enlightenment is admirable, but what we cannot do is transcend our particularity in any absolute manner, and it is here where we need to listen to what the postmodernists have to say. For Nagel, this quest for self-transcendence is bound up with a realist account of human knowledge-that is, an account in which "the universe and most of what goes on in it are completely independent of our thoughts" $(1986$, p. 92). Without this approach of "critical realism" with its critical search for truth about objective reality, we remain stuck in the quagmire of relativism or scepticism, and, as Bailin points out, we further have "no means for arguing against intolerant, anti-democratic or tyrannical points of view" (1992, p. 68).

What I am proposing, therefore, is a reconciliation of the insights of modernism and postmodernism concerning epistemology and human nature which avoids the extremes in either position. 30 The fundamental problem with modernism is that it bears all the marks of an over-reaction. Postmodernism has arisen, I would suggest, as a corrective to this overemphasis on the universal and the non-particular inherent in modernism. But postmodernism, too, is in danger of over-reacting and, hence, the relativism and radicalism that pervades academia today. What is needed is a middle way, a reconciliation between the legitimate insights in both modernism and postmodernism.

This will lead to a balanced view of academic freedom in which it is acknowledged that, while teachers and researchers are unavoidably rooted within a tradition, they will invariably also be seeking to transcend their limitations in an ongoing search for truth. While the notion of pure freedom is an illusion, the notion of "a view from nowhere" must be kept as a heuristic principle in order to encourage an open-minded search for truth. What this will lead to is an ideal of "normal academic freedom." 31 Normal academic freedom maintains a proper balance between an acceptance of the limitations that are inherent in academic work and a striving to move beyond these limitations in the search for truth.

\section{Academic Freedom in Religious Schools}

We are now in a position to answer the charge that the ideal of academic freedom is violated in religiously-based colleges and universities, or that such schools are inferior because they can only have a limited degree of academic freedom. This charge rests on a muddled, unrealistic, and philosophically indefensible concept of academic freedom. Once this concept is updated so as to acknowledge the inescapable limitations of freedom that accompany teaching and research in any context, then the religious commitment of these schools does not of necessity entail the absence of academic freedom.

The "limitations clause" in the AAUP 1940 Statement of Academic Freedom unfairly singles out religious institutions as having only limited academic freedom. All institutions have limited academic freedom. Hence, a 11(2), (Winter) 1998 
more honest approach to academic freedom would be to see the limitations clause as applying to all institutions. Both those defined as serving the public, as well as those serving religious communities, should openly state the actual bounds of their academic freedom. ${ }^{32}$

At the same time, it should be stressed that all schools, religious as well as secular can and should be engaged in an open and honest search for the truth. This openness, however, should be coupled with an equally open admission of the limiting context within which this search for truth is being conducted. ${ }^{33}$

It might be appropriate here, by way of implication, to comment on Father Curran's position referred to earlier. The basic thrust of his book is to argue for full academic freedom in Catholic institutions of higher education. However, towards the end of his book, when he discusses the role of Catholic theologians, Curran maintains that they should theologize within the parameters of the Catholic faith, and that any Catholic theologian who does not accept Jesus' divinity, for example, could be dismissed for incompetence (Curran, 1990, pp. 181-8). But surely, as Kliever (1988) has pointed out, this is to adopt a position of limited academic freedom. Curran tries to cover up this inconsistency by talking about competence as a professional criterion. A Catholic theologian who does not accept Jesus' divinity should be seen as professionally incompetent. While I agree that this doctrinal position might raise questions about competence within a Catholic seminary, the fact still remains that we can no longer talk about full academic freedom within this context.

The revised ideal of academic freedom proposed in this paper further entails that religious colleges should not be seen as having inferior status to secular colleges because of the limits to academic freedom that exist due to religious commitments. As Marsden puts it, "colleges and universities that represent alternate viewpoints, based on traditional Christian and other religious commitments, should be fully recognized as equally legitimate with those who have claimed universality on the basis of the alleged authority of value-free science"' $(1993$, p. 233).

This is not to say that violations of academic freedom at religious schools do not occur just as they do at secular colleges and universities. My primary concern here is only to argue that academic freedom is possible at religious schools and that the religious commitment that pervades such institutions does not in and of itself negate the possibility of academic freedom.

\section{Towards Educational Pluralism}

It might still be argued that there is a greater degree of academic freedom at a secular university because it allows for a plurality of viewpoints and is neutral with regard to which initial commitments its teachers and researchers use as their basis for the search for truth. ${ }^{34}$

Clearly, there is a difference here between church-related colleges and secular colleges or universities. But the difference is not as great or as significant as is generally assumed. McConnell points out that it is not unusual for some university departments to have a disproportionate concentration of faculty representing a particular school of thought within a discipline $(1993$, p. 319 , footnote 48). And there is an obvious prejudice against attempts to introduce religious interpretations of truth within academic disciplines in most university classrooms (McConnell, 1993, p. 315). There would further seem to be an 
insistence on only one model of truth-seeking at our secular colleges and universities (McConnell, 1993, p. 312). ${ }^{35}$ And, as stated earlier, we can find a clear bias towards a scientific model of truth-seeking in the early AAUP formulations of the principles of academic freedom. Indeed, the overall alleged neutrality of universities is being seriously challenged in our day from a variety of standpoints-critical theory, neo-Marxism, and feminism (see Tierney, 1993).

Moreover, although some plurality may exist at secular universities, it is primarily a plurality of individuals. If, as I have already argued, truth is found within epistemic communities, as the postmodernists maintain, then perhaps a healthier kind of pluralism could be found in a plurality of educational institutions, where each is committed to finding truth based on its particular standpoint. Individuals by themselves are in a position of weakness in terms of challenging established opinion. Within a system of educational pluralism, if each educational institution allowed the results of individual inquiry to be critiqued by those within the institution, as well as by those in other institutions, starting from very different presuppositions, I believe this would enhance the larger human quest for truth more effectively than our present arrangements of monolithic state-supported systems of education. ${ }^{36}$

Of course, such an arrangement presupposes a level of tolerance and respect for other educational institutions and other understandings of reality. But these virtues are not precluded by healthy religious commitments. ${ }^{37}$ And for those who like to extol these virtues from a liberal point of view, I would suggest that they themselves need to display greater levels of tolerance and respect towards religious educational institutions. As McConnell has reminded us, it is surely important that the principle of academic freedom which was born of opposition to dogmatism should not itself become dogmatic and authoritarian (1993, p. 314).

\section{Some Concluding Observations}

Clearly, although one aim of this paper has been to clarify some of the vagueness and ambiguity surrounding the concept of academic freedom, it should be apparent that some vagueness still persists. While I have argued that limitations to academic freedom are inescapable, and that there must be a balance between limitations and freedom, this balance has not been precisely defined. I do not believe it can ever be defined with mathematical precision.

In religious schools with a healthy academic atmosphere, there will be both clearly defined limitations to academic freedom, as well as the freedom to think creatively on the basis of the accepted religious commitments of the school. Healthy religious educational institutions should also have mechanisms in place for periodic reflection upon their operating assumptions (Hardy, 1995, p. 17). Indeed, there should be ongoing reflection and critical evaluation of the fundamentals within any healthy tradition or educational institution which bears that tradition as Alisdair MacIntyre has argued. ${ }^{38}$ However, a continuity and a clear institutional identity is also needed. Here again, a balance needs to be maintained between these two emphases, though we should be careful again not to expect a precise definition of a proper balance.

While this paper has focused primarily on religiously committed educational institutions, let me reiterate that all schools have limited freedom and, therefore, the "limitations clause" should be seen as also being applicable to 11(2), (Winter) 1998 
secular colleges and universities. If this point were acknowledged, and if our state-maintained colleges and universities were required to declare openly the boundaries to academic freedom that, in fact, exist within them, it might just lead to considerable embarrassment about what the boundaries to research and teaching are, and how many such limiting boundaries there are. ${ }^{39}$ It might even prompt a redefinition of the limitation clauses that implicitly exist at our secular institutions leading to a greater degree of academic freedom!

Sadly, there is an arrogance that tends to pervade the secular establishment, and a peculiar blindness to the biases that exist within it. ${ }^{40}$ I would suggest as one piece of evidence of this blindness, the failure to revise, or even to consider revising, the ideal of academic freedom in the light of the radical shifts in our thinking about epistemology and freedom that have occurred, and are now generally accepted within academia.

The foundations of the traditional ideal of academic freedom have crumbled, but the secular edifice still stands-but just barely. When it does come tumbling down, hopefully religious schools will be recognized as equal partners with secular schools in being "authentic seats of higher learning."

\section{Notes}

1 Robert M. Mclver (1955) cited in Marsden, 1994, p. 433, as well as in Marsden, 1993, p. 231, footnote 26.

2 Cited in McConnell, 1993, p. 309. McConnell provides a useful review of some of the recent legal literature on this topic.

3 See Hamilton, 1995, p. 160; Russell, 1993, p. 2; Tierney, 1993, p. 145.

4 See McConnell (1993, p. 303). For another helpful and more detailed treatment of the typical principles inherent in the historic, American conception of academic freedom over the past seventy-five to one hundred years, see Horner (1992, pp. 36-7).

5 The statement of academic freedom of the Canadian Association of University Teachers (CAUT) is very similar in orientation to that of the AAUP 1940 statement, though the former is found within the context of a policy statement on academic appointments and tenure and it does not include a specific limitations clause for religious colleges (Goede, 1979, pp. 8ff.). See also the 1977 "Model Clause on Academic Freedom for Collective Agreements and Faculty Handbooks"' (Goede, 1979, p. 46).

6 See Appendix B in Van Alstyne, 1993, pp. 407-9.

${ }^{7}$ Metzger (1993, p. 38) and McConnell (1993, p. 309) correctly point out that more recent developments in the Roman Catholic church as well as in evangelical denominations cast doubt on the empirical basis for this Interpretive Comment. McConnell also points out that organized academia has never articulated any principled justification for the limitations clause accommodating religious colleges and universities. It would seem that its earlier acceptance was mainly a concession made because of the large percentage of institutions which were then under denominational control (McConnell, 1993, p. 311).

8 Many examples of this purely secular interpretation of academic freedom can be found in the reports of AAUP's Committee A on Academic Freedom and Tenure as published in Academe: Bulletin of the AAUP. McCon- 
nell (1993) and Marsden (1993) also cite a good number of cases of censure against religious institutions.

${ }^{9}$ Minutes of the Annual General Meeting of the Canadian Society for the Study of Religion, June, 9, 1993, as reported in the October 1993 issue of the CSSR Bulletin, 17, 1, p. 16.

${ }^{10}$ Cited in McConnell (1993, p. 309). As another example of this bias against religiously-based schools, the prestigious Phi Beta Kappa Society has denied membership to even the best of the many liberal arts colleges of the Christian College Coalition, as well as to the overwhelming majority of the hundreds of Catholic colleges and universities, on the grounds that any religiously-defined standards for teaching are incompatible with academic freedom (Marsden, 1993, p. 233).

11 The secularization of many former Protestant schools can be linked to the acceptance of secular ideal of full academic freedom (cf. Curran, 1990, p. 79). By contrast, David Horner, President of Evangelical North Park College and Theological Seminary, argues that Christian colleges can only have limited freedom because of their hiring policies and their lack of neutrality with regard to truth (Horner, 1992, pp. 36, 38, 39). Others, like Hardy (1995) and Marsden (1993) argue for equal status between religious and secular institutions, though based on a revised notion of academic freedom.

12 Louis Menand, in a recent essay discussing the future of academic freedom, admits that "the concept of academic freedom has always been problematic. It's inherently problematic" (1993, p. 12). Interestingly, although Menand admits that a reconsideration of the concept of academic freedom is needed, he goes on to say that it is impossible to provide a restatement of the philosophical foundations of academic freedom such that everyone will be happy with its practical consequences all the time (pp. 11, 12). Surely we must not give up too soon!

${ }^{13}$ Marsden cites this as an early criticism of the 1940 AAUP statement of academic freedom (1993, p. 229). Curran points out that this is a frequently made criticism by Roman Catholics $(1990$, pp. 26, 39, 58, 116, 158). Of course, disciplinary, professional, and ethical constraints are at times acknowledged, but the ideal still seems to be that of full freedom.

14 Cited in Curran (1990), p. 39.

1515 . Hamilton, for example, places much emphasis on the correlative duties of faculty both as individuals and as a collegial body (1995, Chs. 4, 10; cf. Horner, 1992, pp. 35ff). follow.

16 Further limitations of freedom will be identified in the sections that

${ }^{17}$ In its earlier 1915 Declaration of Principles, AAUP argued for freedom also in the domain of theology: "Such freedom is the breath in the nostrils of all scientific activity" (cited in McConnell, 1993, p. 318). This drawing on the imagery from Genesis 2:7, which states that God "breathed into [Adam's] nostrils the breath of life," cannot help but contribute to a feeling that science is here being deified. See also Hamilton (1995, pp. 160ff) for a further analysis of the liberal intellectual system underlying the American statement of academic
freedom.

18 See Thomas Kuhn (1962 [1970]); Young, 1971; MacIntyre, 1988; Clouser, 1991; Middleton \& Walsh, 1995; and Garry \& Pearsall, 1989. 11(2), (Winter) 1998 
19 See also Marsden, 1993, p. 232; Curran, 1992, p. 21; and Menand, 1992, pp. 11-12, for other calls for an updated statement of academic freedom in the light of recent epistemological developments.

20 The epistemology being appealed to as a basis for a revised ideal of academic freedom is not without its pitfalls, and I will address these in a later section. But we must not let these dangers lead us to hang onto an ideal of academic freedom whose epistemological foundations have crumbled.

21 For one of the most influential criticisms of the extreme individualism inherent in liberalism, see Robert N. Bellah, et al., 1985. See also other communitarian critics of liberalism (Maclntyre 1984; Sandel, 1982). For attempts to maintain a balance between the individual and the community, see Kymlicka, 1989; Macedo, 1990.

22 Caston (1989) contrasts the level of academic freedom in free and non-free societies, and concludes thus: "The political style of a society is thus one important element of the context in which the degree of academic freedom has to be negotiated. It is not a simple free or non-free dichotomy" (p. 310).

23 For a delightful defence of universities as centres for the cultivation of the intellect and the transmission of wisdom, as well as a defence of academic freedom at these "useless" universities where the development of the intellect is valued for its own sake, see O'Hear (1988).

${ }^{24}$ Russell attempts this in his own work, but it is beyond the scope of this paper to evaluate his proposed balance $(1993, \mathrm{Ch} .3)$.

${ }^{25}$ McConnell refers, for example, to a statement made by the 1988 subcommittee of AAUP's Committee A on Academic Freedom and Tenure with regard to a possible alternative rationale for the accommodation of religious schools: "Many of these institutions usefully function as 'decompression chambers' that ease the passage into the larger world for the religiously provincial. The condescension-indeed bigotry - of this suggestion seems to have passed unnoticed" (McConnell, p. 312). See also note 8 for further expressions of concern about religious colleges and universities.

26 A reply to Menand's response to the call to revise the concept of academic freedom in the light of the postmodernist challenge would seem to be unnecessary because Menand relativizes the meaning of academic freedom, and ultimately concedes that there is no need for academic freedom if you think that universities are sites for social indoctrination (Menand, 1993).

27 See Bloom, 1987; Kimball, 1990; D’Souza, 1991; Rauch, 1993. Bailin (1992) quite correctly underscores the profoundly undemocratic consequences of postmodernist critiques of Enlightenment epistemologies.

28 For a defence of objective knowledge, see Helm (1987) and Middleton/Walsh (1995). Similar emphases can be found in Kuhn and Macintyre who have mistakenly been thought to succumb to relativism. Macintyre, for example, after reaffirming his central emphasis that all reasoning takes place within the context of some traditional mode of thought, goes on to talk about "transcending through criticism and invention the limitations of what had hitherto been reasoned in that tradition" (MacIntyre, 1984, p. 222; cf. Kuhn, 1977)

${ }^{29}$ I am indebted to Hart (1995) for this account of Nagel's work.

30 For similar calls for such a reconciliation, see Toulmin $(1990$, p. 175) 
and Weinstein (1995). Jeffrey Stout (1988) also attempts such a reconciliation with regards to ethics. See also references in note 21 for attempts to reconcile a parallel dichotomy between the individual and the community.

31 The qualifier "normal" follows a paradigm I have adopted in an earlier
work (Thiessen, 1993).
32 See Marsden, 1993, p. 233. This is not at all to suggest that religious
institutions cannot also serve the public good. See Bryk et al. (1993) for a strong argument that Catholic high schools do better than public high schools in promoting the basic social and political purposes that once were the inspiration

of American public education and gave them the title of "common school."
33 Marsden provides us with a useful description of academic freedom that maintains a proper balance between limitations and freedom: "To enhance the creativity of the community, academics should be as free as possible within the framework of their other higher commitments to explore and communicate even unpopular and unconventional ideas. A presumption of freedom within defined limits is an immensely valuable way of defining academic life" (Marsden, 1994, p. 434). Much more needs to be done by way of defining what is a proper balance between such limitations and freedom, but this is beyond the scope of this paper.

${ }^{34}$ Horner, for example, sees this institutional neutrality as a key ingredient in the American conception of academic freedom (1992, p. 36).

35 Thomson and Finkin in their critique of McConnell are forced to concede that there is a scientific bias underlying what they suggest would be better called "secular academic freedom," and that there is no way of proving the correctness of either the scientific or the religious model of truth-seeking (1993, pp. 426-9). However, they go on to object to the "coercion" that McConnell seems to endorse in his defence of religiously-based schools. I would suggest that Thomson and Finkin do not really face up to the fact that secular institutions are similarly coercive in limiting academic freedom to a particular model of truth-seeking. Coercive boundaries are simply inescapable, as I have argued. I would argue, however, that the "problem" of coercion can be overcome if the limiting boundaries to academic freedom are clearly spelled out in hiring. A faculty member who then accepts a position at an educational institution voluntarily accepts the institution's boundaries of academic freedom. They count as self-limitations and therefore cannot be seen as infringing on his or her autonomy (Hardy, 1995, p. 10).

${ }^{36}$ Marsden does make a suggestion regarding educational pluralism at the end of his careful historical study of the secularization of the American university, though this suggestion seems to be only tentatively made given the section title- "Concluding Unscientific Postscript" (1994, pp. 436-40).

${ }_{38}^{37} \mathrm{I}$ have argued this point elsewhere (Thiessen, 1985; 1987).

38 MacIntyre describes vital traditions and the institutions that bear these traditions as being constituted by a "continuous argument," and as embodying "continuities of conflict": "A living tradition then is an historically extended, socially embodied argument ... " (Macintyre, 1984, p. 222-see also footnote 28).

39 To gain an awareness of the boundaries to academic freedom that, in fact, do exist at secular institutions, I would recommend Hamilton's excellent summary of seven waves of ideological zealotry that have swept American 11(2), (Winter) 1998 
universities over the past 125 years, and which have threatened, and continue to threaten the ideal of academic freedom as typically understood (1995, Chs.1 \& 2). For a description of widespread violations of academic freedom during the McCarthy era, see Schrecker (1986). Of course, as was pointed out earlier in this paper, these violations will sometimes have been rationalized in some way, thus leading to revised notions of academic freedom-limited academic freedom!

40 Marsden too suggests that the refusal to accept religious schools as equal partners in the pursuit of truth can only be described as "sheer prejudice" on the part of the secular establishment (Marsden, 1993, p. 234). See also comments in note 25 .

\section{References}

Bailin, Sharon (1992). "Culture, Democracy, and the University," Interchange, 23(1\&2), 63-9.

Bellah, Robert et al. (1985). Habits of the Heart: Individualism and Commitment in American Life. Berkeley: University of California Press.

Bloom, A. (1987). The Closing of the American Mind. New York: Simon \& Schuster.

Bryk, Anthony S. et. al. (1993). Catholic Schools and the Common Good. Cambridge, MA: Harvard University Press.

Carr, Wilfred (1995). "Education and Democracy: Confronting the Postmodernist Challenge," Journal of Philosophy of Education, 29(1), 75-91.

Caston, G. (1989). "Academic Freedom: The Third World Context." Oxford Review of Education, 15(3), 305-38.

Clouser, Roy A. (1991). The Myth of Religious Neutrality: An Essay on the Hidden Role of Religious Belief in Theories. Notre Dame, IL: University of Notre Dame Press.

Curran, Charles. E. (1990). Catholic Higher Education, Theology, and Academic Freedom. Notre Dame \& London: University of Notre Dame Press.

D'Souza, D. (1991). Illiberal Education: The Politics of Race and Sex on Campus. New York: Free Press.

Garry, Anne \& Marilyn Pearsall (1989). Women, Knowledge and Reality. Boston: Unwin Hyman.

Goede, William (1979). Handbook of Policy Statements, Guidelines and Model Clauses (3rd. ed.). Ottawa: Canadian Association of University Teachers.

Hamilton, Neil W. (1955). Zealotry and Academic Freedom: a Legal and Historical Perspective. New Brunswick \& London: Transaction Publishers.

Hardy, Lee (1995). "Between Inculcation and Inquiry: The Virtue of Tolerance in the Liberal Arts Tradition." Presented at the RUNA (Reformed University in North America) Conference, Grand Rapids, Michigan, March 24-25, 1995. Pamphlet, pp. 5-26.

Hare, William (1979). Open-mindedness and Education. Kingston \& Montreal: McGill-Queen's University Press.

Hart, Trevor (1995). Faith Thinking: The Dynamics of Christian Theology. London: SPCK. 
Haworth, Lawrence (1986). Autonomy: An Essay in Philosophical Psychology and Ethics. Notre Dame, IL: University of Notre Dame Press.

Helm, Paul (1987). Objective Knowledge: A Christian Perspective. Leicester: Inter-Varsity Press.

Horner, David G. (1992). “Academic Freedom," Faculty Dialogue, 17(Winter), 35-41.

Kimball, R. (1990). Tenured Radicals. New York: Harper and Row.

Kliever, Lonnie (1988). "Academic Freedom and Church-Affiliated Universities," Texas Law Review, 66(7), 1477-80.

Kuhn, Thomas S. (1962[1970]). The Structure of Scientific Revolutions (2nd. ed.). Chicago: University of Chicago Press.

Kuhn, Thomas S. (1977). "Objectivity, Value Judgment and Theory Choice,' In The Essential Tension. Chicago: University of Chicago Press, pp.
320-339.

Kymlicka, Will (1989). Liberalism, Community and Culture. Oxford: Clarendon Press.

Macedo, Stephen (1990). Liberal Values; Citizenship, Virtue and Community in Liberal Constitutionalism. Oxford: Clarendon Press.

Marsden, George M. (1993). "The Ambiguities of Academic Freedom," Church History, 62, 221-36.

Marsden, George M. (1994). The Soul of the American University: From Protestant Establishment to Established Nonbelief. New York and Oxford: Oxford University Press.

MacIntyre, Alasdair (1984). After Virtue (2nd. ed.). Notre Dame, IN: University of Notre Dame Press.

don: Duckworth.

MacIntyre, Alasdair (1988). Whose Justice? Which Rationality? Lon-

McConnell, Michael W. (1993). "Academic Freedom in Religious Colleges and Universities." In William W. Van Alstyne (ed.) Freedom and Tenure in the Academy, Durham \& London: Duke University Press, pp. 30424.

Menand, Louis (1993). "The Future of Academic Freedom," Academe: Bulletin of the AAUP, 79, 11-17.

Metzger, Walter P. (1993). "The 1940 Statement of Principles on Academic Freedom and Tenure." In William W. Van Alstyne (ed.) Freedom and Tenure in the Academy, Durham \& London: Duke University Press, pp.
3-77.

Middleton, J. Richard \& Brian J. Walsh (1995). Truth is Stranger Than It Used To Be: Biblical Faith in a Postmodern Age. Downers Grove, IL: InterVarsity Press. University Press.

Nagel, Thomas (1986). The View From Nowhere. New York: Oxford

O'Hear, Anthony (1988). "Academic Freedom and the University," Journal of Philosophy of Education, 22(1), 13-21.

Polanyi, Michael (1946[1964]). Science, Faith and Society. Chicago \& London: The University of Chicago Press.

Rauch, Jonathan (1993). Kindly Inquisitors: The New Attacks on Free Thought. Chicago: The University of Chicago Press.

Russell, Conrad (1993). Academic Freedom. London: Routledge. 
Sandel, M. (1982). Liberalism and the Limits of Justice. New York: Cambridge University Press.

Schrecker, Ellen W. (1986). No Ivory Tower: McCarthyism and the Universities. New York: Oxford University Press.

Stout, Jeffrey (1988). Ethics After Babel: The Languages of Morals and Their Discourses. Boston: Beacon Press.

Thiessen, Elmer John (1985). "Proselytizing without Intolerance," Studies in Religion, 14(3), 333-45.

Thiessen, E.J. (1987). "Educational Pluralism and Tolerance," Journal of Educational Thought, 21(2), 71- 87.

Thiessen, E.J. (1993). Teaching For Commitment: Liberal Education, Indoctrination and Christian Nurture. Montreal \& Kingston: McGill-Queen's University Press.

Thomson, Judith Jarvis \& Matthew W. Finkin (1993). "Academic Freedom and Church-related Higher Education: A Reply to Professor McConnell." In William W. Van Alstyne (ed.) Freedom and Tenure in the Academy, Durham \& London: Duke University Press, pp. 419-29.

Tierney, W.G. (1993). "Academic Freedom and the Parameters of Knowledge," Harvard Educational Review, 63(2), 143-60.

Toulmin, Stephen (1990). Cosmopolis: The Hidden Agenda of Modernity. New York: The Free Press.

Van Alstyne, William W. (1993). Freedom and Tenure in the Academy. Durham \& London: Duke University Press.

Weinstein, Mark (1995). "'Social Justice, Epistemology and Educational Reform," Journal of Philosophy of Education, 29(3), 369-86.

Young, Michael F.D. (Ed.) (1971). Knowledge and Control: New Directions for the Sociology of Education. London: Collier-MacMillan. 